\title{
Practicability Analysis of Case Teaching in Vocational College Teaching
}

\author{
Xiaoqian Chen \\ Shandong Vocational College of Foreign Affairs Translation \\ Weihai, Shandong, 264504, China \\ Email:vozo@sina.com
}

\begin{abstract}
Case teaching shows favorable practical effect in vocational teaching, for it can uplift the teaching quality of vocational colleges. This paper, through comparing the teaching effects of classes using case teaching method and traditional teaching method respectively, introduces cases into the teaching of legal majors. It comes to the conclusion that the effect of case teaching method is obviously better than that of traditional teaching method, hence providing reference for future vocational teaching reform.
\end{abstract}

Keywords: vocational teaching, case teaching, legal education, innovation

\section{INTRODUCTION}

In essence, case teaching is a new open and interactive teaching approach. Through careful planning and preparation in advance, it guides students to conduct pre-reading of specific cases and organizes them to carry out discussions or debate. Case teaching normally goes with certain theories, so as to reach the goal of enlightening theories and inspiring thinking through collision of various information, knowledge, experience and ideas.

\section{OVERVIEW OF CASE TEACHING DEVELOPMENT}

Case teaching is an interactive students-centered process that focuses on exploring practical problems or certain fact, i.e., a process of organizing students to conduct self-study, uplifting their practical ability and cultivating their innovation awareness. Therefore, in teaching, teachers should center on students and fully utilize learning environment elements like dialogue, cooperation and situation to give play to students' initiative, activeness and pioneering spirit, and ultimately develop talents suitable for market demand and future changes [1].

Case teaching emerged from the School of Management, Harvard University in 1918, when the teaching faculty had already applied practical cases into classrooms and imparted knowledge through discussions. Since the 1980s, China adopted the method of case teaching. Over more than 30 years of development, case teaching has been accepted by more and more people, and even enlisted into educational reform plan. As a whole, the promoted application of case teaching method in China is still in the primary stage.

However, compared with foreign vocational colleges, their Chinese counterparts see a small proportion of teaching. Take the Business School of Harvard as an example. In 1920, the School, under the funding of Rockefeller group, officially applied case teaching into classrooms, and started to organize case teaching for different disciplines [2]. Katherine K. Merseth, the current Dean of School of Business in Harvard University, makes an utmost effort in promoting case teaching [3], so that most courses have been delivered through case teaching, with the proportion of case teaching in the School reaching as high as $90 \%$ [4]. However, the occupation ratio of case teaching class hours in China is only 30\% [5], which is far from satisfying the need of professional talents cultivation. Although many vocational colleges has started to pay attention to the application of case teaching, the methods in obtaining cases remain behind and the cases collected are relatively outdated, so the ideal effect is hard to reach [6]. As a special inductive teaching method, although case teaching could not completely replace deductive teaching mode, it turns out to be an irreversible trend of reform direction for vocational teaching [7].

\section{ADVANTAGES OF CASE TEACHING}

\section{A. Case Teaching Method Pays Attention to Cultivating Students' Comprehensive Practical Ability}

In vocational teaching, if teachers adopt the method of case teaching, they need to accurately analyze the main content of current teaching, teaching objective and students' practical ability, and then select representative teaching cases and combine with the knowledge of course to ask the students to conduct theoretical analysis and discussions. In this way, students can gradually uplift their own comprehensive ability through practical application of knowledge. When students are conducting analysis and cases, teachers have to organize timely and guide students to widen their thinking, draw inferences and actively combine theoretical knowledge with practice while preventing them from slipping into deviation or awkward silence, etc.

\section{B. Different Angles of Case Analysis among Students Help Realize Diverse Answers}

The cases in vocational teaching are extracted by teachers from specific theories in teaching work, and they can effectively guide the students to learn professional courses and uplift their ability of analyzing practical issues. Therefore, students are stimulated to look at problems from different angles, thereby forming their own answers. In addition, the open questions have no standard answer, as long as the students make their sense. The teachers encourage the students to speak out their mind, which can 
deepen their understanding of auditing knowledge and uplift their ability of solving practical problems.

\section{Fresh Cases can Effectively Cultivate Students' Operation Ability}

In vocational teaching, teachers can select hotspot social issues as teaching cases, which can enhance students' understanding of professional knowledge. Through the representation of those real cases, students can utilize their learned theoretical knowledge to analyze the hotspot issues. This serves as a sound way to deepen legal theoretical knowledge, because on one hand it can consolidate students' mastery of legal theoretical knowledge, and on the other hand help uplift their operation ability in analyzing cases, hence laying a solid professional foundation for their future career.

\section{ANALYSIS OF PROBLEMS IN VOCATIONAL COLLEGE TEACHING}

1. In recent years, the number of vocational students has been climbing, so that the teaching resources are increasingly showing obvious shortage; combined with the failure of traditional vocational teaching method to satisfy the social requirements upon vocational students, a series of problems have been caused. Students lose their interest in specialty, and teaching quality and training objective finally lose the deserved features of vocational education. The teaching process lacks relations with reality, mostly because the teachers are not systematically trained, so they lack the thinking of linking theory with practice, ignore the importance of practice to vocational students, and ultimately deviate from the goal of vocational education.

2. In vocational education, the textbooks adopted mostly are partial to basic theories, emphasizing definitions yet despising cases, which make the education of vocational colleges unable to highlight their own rules and characteristics. In vocational education, textbooks about professional skills lack, with one-sided emphasis of realizing scientificness while imparting few knowledge about skill and practice. In the long run, the teaching method with a focus on theory to the neglect of ability will no doubt cause insufficient operation ability among vocational students, loss of characteristics of vocational education, and more challenging employment for the students.

3. The traditional methods of vocational teaching tend to be outmoded and monotonous, without any deserved characteristics, for vocational colleges mainly adopt the educational methods of common institutions of higher learning with an emphasis of theoretical knowledge. The teaching notions do not conform to vocational teaching. For example, in vocational colleges, there are still teachers equipped with one chalk and one mouth reciting from start to end. The mode of cramming holds a dominant position, failing to display the philosophy of centering on students as subjects. The teaching methods in common institutions of higher learning ignore the characteristics and practicalness of vocational school learning, leading to severe shortage of case teaching, many cases only existing in name yet failing to give play their role.

\section{V.FEASIBILITY OF APPLYING CASE TEACHING IN VOCATIONAL TEACHING}

On the basis of the above analysis of problems in current vocational education, this part will dissect the feasibility of applying case teaching in vocational education.

\section{A. Implementing Case Teaching Conforms with the Practicalness of Vocational Colleges}

The goal of vocational education lies in enabling students to use the learned knowledge to analyze and handle problems in life and production, pay attention to the social issues related to various disciplines, cultivate their thinking of actively participating in social decision-making, and forming positive and striving attitude in study and life. Case teaching is to enable students of vocational colleges to obtain a deeper understanding of the learned specialty through analyzing the practical cases from various disciplines. Moreover, drawing on the specialty, they are allowed to be exposed to practical problems in society, thereby obtaining the training necessary for participating in social decision-making.

\section{B. Implementing Case Teaching is Consistent with the Direction of Vocational Education}

The goal of vocational education also lies in enabling students to face society and job position, so they need not only theoretical foundation but also work ability. Nevertheless, case teaching combines theory with practice, which on one hand deepens students' understanding of theory, and on the other hand enhances their ability of operation, hence consolidating the vocation-orientation of vocational education. Another direction of vocational education moves to uplifting the professional competence of students to become real professional talents. Case teaching method combines theory in textbooks with practice, proposes issues related to practical work and leaves space for students to think, so that students have sufficient time to think independently, analyze and solve problems. The knowledge learned in this process is further applied into practice, hence uplifting their comprehensive ability. Case teaching method can not only improve students' ability of analyzing and solving problems independently, but also allow them to grasp systemic knowledge, hence providing the feasibility for vocational education to uplift students' disciplinary competence.

\section{Implementing Case Teaching is to be Unified with Developing Vocational Education into Characteristic Education}

The society is inevitably to be a "knowledge-based society" and "intelligence and value unified society", which will fundamentally change the current "industrialized society". Some people critize that the modern schools in China are "factory-like ones", where the humanistic ideas are faint, singular and ossified ${ }^{[8]}$. The ultimate goal of quality-oriented education lies in equipping students with individuality, diversity and independent innovation. Nonetheless, case teaching 
method can realize the communication between teachers and students; through case discussions, students are given the space to show themselves while the teachers are allowed to pay attention to students as individuals, thus realizing individualized education. Traditional vocational education emphasizes lecturing and stresses on uniformness, so that the classroom becomes "lecture room". This strikes a stark contrast between one-sided lecturing and passive reception. Case teaching can fully mobilize the subjective initiative and positivity of students to conduct independent and autonomous explorative learning and cultivate their interest in learning as well. This in fact turns out to be a sound cyclic learning method of "learning from doing" and "learning based on need". Learning in real situations usually produces the effect of getting twofold results with half the effort.

\section{INVESTIGATIVE ANALYSIS OF CASE TEACHING}

The framework of current legal textbooks is mainly based on the theoretical system of courses, the goal of which lies in requiring the students to grasp the basic meanings and features of laws, yet to the neglect of legal application in practical life. The legal textbooks don't set up relevant cases, or the cases set up are relatively outdated, having no characteristics of the era. Only in the part of practice, are there several old cases involving procedure. In the part of theory, there is no support of cases, so that beginners may find learning of legal theories boring or even hard to understand.

Therefore, after comparative and investigative statistics of case teaching method and common teaching method for students in vocational education, it can be known that the key of legal teaching lies in teaching method, which plays a vital role in guiding students to learn and creating classroom atmosphere. Traditional method is relatively boring, which will make students lose their interest, hence affecting their performance. Through comparing the background of the two teaching theories, it is revealed that case teaching method boasts a variety of advantages that cannot be found in lecturing teaching, while what the reformers of vocational education promote is exactly the advantages of case teaching, which serve well the needs of Chinese social development. The students featuring high scores and low abilities are not the goal of educators in vocational teaching, and instead what they need to cultivate is talents with characteristics of the new era. Therefore, case teaching is essential for vocational teaching.

\section{CONCLUSION}

Case teaching is formed through students' discussions and teachers' summarization. Students are normally divided into groups for exploration, in which students tend to be very positive. The conclusions obtained by every group may deviate somehow, which, however, does not matter anyway, for what is important is to allow students to feel the charm of professional knowledge, and experience that knowledge is right with us, which will significantly help the employment or entrepreneurship of students after graduation. The application of case teaching method in classrooms can not only uplift students' interest in learning professional courses, but also stimulate their initiative and positivity in learning as well. More importantly, it promises to cultivate students' ability of applying professional knowledge to think about and solve practical problems.

\section{REFERENCES}

[1] Jon Bochrer. Case Teaching in Higer Education [J]. Home Page, 1999-03-23.

[2] Wang Fengling, Cui Yulin. Case Teaching: An Effective Method of Developing Students' Innovative Thinking and Transferable Skills: Practical Case Teaching Design [J]. Journal of Beijing International Studies University, 2003, 114(2): 14-16.

[3] Huang Juanjuan. Educational Case and Case Study, Case Teaching [J]. Studies in Preschool Education, 2003(11): 32-33.

[4] Liu Shuang. Analysis of Several Issues in "Case Teaching" [J]. The Inservice Education and Training of School Teachers, 2003(3): 51-52.

[5] Wang Zhiyong, Zhang Wenxia. A Teaching Mode Facing the $21^{\text {st }}$ Century: Case Teaching $[\mathrm{J}]$. Journal of Shandong Education Institute, 2003, 98(4): 24-25.

[6] Luo Ding. Practice of and Research on Middle School Environment Case Teachers [J]. Environmental Education, 2001(6): 37-38.

[7] Yuan Zhenguo. Education Rationale [M]. Shanghai: Huadong Normal University Press, 2001.

[8] Xie Anbang. Advanced Education [M]. Beijing: Higher Education Press, 1999. 